\title{
THE DEPTHS OF MODERN SAND CLINOFORMS
}

Running head: $\quad$ DEPTHS OF MODERN COASTAL SAND CLINOFORMS

Neil C. MitChell ${ }^{1}$, Gerhard MASSElink ${ }^{2}$, John M. HuthnAnCE ${ }^{3}$, Luis M. FernándezSALAS $^{4}$ AND FRANCISCO J. LOBO 5

${ }^{1}$ School of Earth, Atmospheric and Environmental Sciences, University of Manchester, Williamson Building, Oxford Road, Manchester M13 9PL, UK

${ }^{2}$ School of Marine Science and Engineering, University of Plymouth, 12 Kirkby Place, Drake Circus, Plymouth, Devon PL4 8AA, UK

${ }^{3}$ National Oceanography Centre, Liverpool, Joseph Proudman Building, 6 Brownlow Street, Liverpool L3 5DA, UK.

${ }^{4}$ Instituto Español de Oceanografía, Centro Oceanográfico de Málaga, Puerto Pesquero, s/n, Fuengirola 29640, Spain.

${ }^{5}$ Instituto Andaluz de Ciencias de la Tierra (CSIC-Universidad de Granada), Avenida de las Palmeras no 4, Armilla 18100, Spain.

Keywords: bedload transport, sandy clinoforms, infralittoral prograding wedge.

This is a pre-publication version of an article published in the J. Sedimentary Research in 2012: http://dx.doi.org/10.2110/jsr.2012.40 
Abstract. Clinforms are classical geological features. Examples in the rock record or in seismic reflection data that originally formed in shallow water can potentially help to locate paleo-sea level, but their precise links with sea level need to be established using modern examples before such inferences can be made accurately. Some near-shore areas of high wave energy and steep coasts host sand bodies with upwards-convex surfaces. These clinoforms have been suggested to have been created from sand exported from the upper shoreface during stormy conditions, and deposited at depths where wave action diminishes below the threshold of motion (Field and Roy 1984; Hernández-Molina et al. 2000). We have compiled the shapes of these bodies in a variety of wave environments in order to test this idea. The interpreted depths at which the sand surface steepens (i.e., the clinoform rollover) vary from $21 \mathrm{~m}$ off southern California to deeper than $50 \mathrm{~m}$ off SE Australia. To assess the link with wave action, rollover depths were compared with adjacent deep-water wave properties over the period 1992-2001 in the ERA-40 reanalysis dataset. Rollover bed shear stresses were computed from properties representing average wave conditions and from properties associated with upper-percentile conditions. Stresses were found to reach $0.1-0.5$ Pa during upper 5-percentile wave conditions, exceeding the sediment threshold of motion estimated from reported grain-size data. Sediment to below the rollover is therefore mobile during extreme wave conditions.

\section{Introduction}

Sediment bodies generated when particles are transported into calmer water and deposited down a slope often form sigmoidal clinoforms (Sangree and Widmier 1977). Between their topsets and foresets, their upwards-convex surfaces, which are often termed "rollovers", are interpreted to arise from a gradual seaward decline in energy of the environment: in shallow 
water, strong currents due to waves and other processes flatten sediment topography, whereas in deeper water, where currents are weaker, sediment can form steeper deposits. These features lie below sea level at the time of deposition. Reconstructing past sea level from seismic reflection data relies primarily on identifying and dating erosional unconformities (Helland-Hansen and Hampson 2009; Rabineau et al. 2006; Vail et al. 1977). Rollovers in stratigraphy may assist that effort, providing an easily identified stratal shape in seismic reflections that is readily traced to the unconformities, but the accuracy of that assistance would depend on the precise depth at which they were originally deposited. Significant research effort has been expended attempting to understand or simulate the shapes of clinoforms (Flemings and Grotzinger 1997; Friedrichs and Wright 2004; Kaufman et al. 1991; Mitchell and Huthnance 2007; Niedoroda et al. 2005; Parker 2006; Pirmez et al. 1998; Rivenaes 1992; Rivenaes 1997; Schlager and Adams 2001; Swenson et al. 2005; Syvitski and Daughney 1992; Walsh et al. 2004). Many of the clinoforms studied to date were formed of muddy sediment, where transport and deposition are potentially complicated, for example, by uncertain settling rates of variably flocculated clay particles and varied resistance to intermittent resuspension arising from compaction and other processes (McCave 1984). Developing a quantitative understanding may be better carried out on sand-grade sediment for which transport and deposition are more predictable (Soulsby 1997).

The clinoforms studied here are subtidal sand lenses or wedges occurring on steep coasts with relatively high wave energy (mean significant wave height $H_{s}$ typically around $2 \mathrm{~m}$ ). They are up to a few tens of meters thick with forms that are convex upwards in shore-normal profile and either elongated along-shore or convex-seawards in plan view. They were first reported off the SE coast of Australia by Field and Roy (1984), who noted that they contain seaward-dipping reflectors in high-resolution seismic reflection images. Such dipping foreset 
strata imply, as with other clinoforms, that these features grow by sequential deposition along their foresets. Consequently they have also been called "infralittoral prograding wedges" (Hernández-Molina et al. 2000). According to Field and Roy (1984) and Hernández-Molina et al. (2000), they originate from suspension and bedload transport of sand from the shoreface and surf zone during storms, with the sand being deposited along the foresets where wave agitation declines towards the threshold of movement.

Given the prograding geometry of sandy aggrading clinoforms (Field and Roy 1984; Hernández-Molina et al. 2000; Lobo et al. 2005), a rapid increase in time-averaged deposition rate occurs going seaward over the rollover, towards a maximum on the clinoform foreset (Friedrichs and Wright 2004). This is illustrated in Figure 1, where the area between two time surfaces represents an increment of net deposition. Walsh et al. (2004) estimated that the rollovers of muddy clinoforms in the Gulf of Papua coincide approximately with the depths at which bed shear stresses due to wave and tidal currents can only just resuspend mud (comparing the bed shear stress to the critical shear stresses of sediment erosion and deposition). The rollover may therefore reflect a critical threshold. However, during quiescent conditions, sediment likely is deposited on the topset of the clinoform as well as on its foreset, and in extreme conditions sediment on some part of the foreset may become mobilized. The clinoform shape results from sediment accumulating over many wave and other events of varying magnitude. Whether one part of the wave-climate spectrum controls the rollover depth or a more complicated combination of the whole spectrum is therefore unclear. Unfortunately, detailed data on in situ wave and current conditions are relatively limited on these sandy clinoforms and, as far as we are aware, no study exists with a level of detailed information comparable to that on the Gulf of Papua clinoforms (Walsh et al. 2004). Rather than address the sediment dynamics of a particular site, the following analysis instead 
seeks to address this issue by comparing clinoforms from several different locations with contrasting rollover depths and with contrasting wave climates (Figure 2). Although the term "rollover" describes the progressive steepening across the tops of clinoforms (i.e., a transition), in order to compare the rollovers with each other and wave data, a point in the steepening profile needs to be identified, so "rollover depth" in the following refers to this specific location. The analysis is restricted to exposed coasts, where local wave-induced shear stresses can be estimated using a global dataset of deep-water wave properties (the ERA-40 dataset derived from reanalysis of meteorological station data verified against wave buoy data; Caires and Sterl 2003; Caires et al.2005). We have sought to correlate local sediment erosion/deposition threshold stresses at the rollovers with bed shear stresses created separately by average wave conditions and by those conditions of the upper 10-percentile and 5-percentile by wave height. If wave-induced bed shear stress dominates the rollover position, this analysis ought to reveal a straightforward correlation with critical sediment thresholds.

\section{Compilation of data of Sandy Clinoforms}

We have interpreted sandy clinoforms from various geophysical data, mostly published seismic reflection data capable of resolving internal structure. Rather than reproduce the data for all these sites here, for brevity they are only summarized. The reader is referred to the maps and further details in the linked publications for details. The sources are listed in Table 1, and interpreted profiles are shown in Figure 3.

Mediterranean Iberia Hernández-Molina et al. (2000) showed one boomer seismic profile (Figure 4B) from the Mediterranean coast of Iberia near Almería south of the Cabo de Gata 
headland, where the lesser fetch compared with the Atlantic leads to shorter-period and lower-amplitude waves. Multibeam sonar data collected nearby (Fernández-Salas et al. 2009) reveal that these clinoforms commonly form a series of en échelon bodies, suggesting that offshore sand export can have a component alongshore in this area. Multibeam data over this particular site (Figure 4A) show a body of sediment rounded in plan view and with a smooth surface texture around the rollover. Surface grab samples have been taken $1 \mathrm{~km}$ seaward and $1 \mathrm{~km}$ landward of the clinform rollover in the Hernández-Molina et al. (2000) profile (Figure 4A). Their median grain sizes are 0.239 and $0.171 \mathrm{~mm}$, respectively.

The stratigraphy within Figure 4B illustrates that these sand bodies can develop by a somewhat complicated history of particle accumulation. Immediately above the transgression surface in Figure 4B, a shallow-dipping stratigraphy onlaps the transgression surface, possibly representing sediments deposited during transgression. They in turn are overlain by a wedge of prograding foresets, which are progressively steeper to the southeast. Despite such a development, we anticipate the modern rollover depth to correspond to a particular threshold shear stress if wave agitation controls the rollover's modern form. We return to this issue in the discussion.

Oceanside California The Oceanside data consist of two lines of chirp sediment-profiler data collected perpendicular to the California coast just north of Scripps Canyon (Hogarth et al. 2007; Le Dantec et al. 2010), which revealed the underlying Holocene transgressive erosional surface (gray lines in Figure 3). In multibeam sonar data (Hogarth et al. 2007), the surface of the sand body is two-dimensional, being uniform along-coast. Above some reflectors onlapping the transgression surface (similar to those in Figure 4B), the body is transparent in these profiler data (internal reflectors are not visible), so little information on depositional history is available. However, that transparency also implies a relatively uniform acoustic 
impedance and likely uniform sediment texture, which is to be expected if the sediments originate from erosion of the local cliffs containing Pleistocene beach sediments sorted by earlier geological periods of wave action (Young et al. 2010) and wave-sorted sediments transported alongshore from rivers to the north (Hogarth et al. 2007). This recent phase of strong wave activity may have started with intensified El Niño activity after 5 ka (Masters 2006).

Le Dantec et al. (2010) suggested that wave activity has controlled or modulated the deposition of the transparent sediments on the shelf here, and that deposition started some time after $8.27 \mathrm{ka}$ based on the age of underlying estuarine sediments. Three vibracores have been recovered through this sediment. One vibracore just south of Scripps Canyon $(1 \mathrm{~km}$ south of the second profile in Figure 3) penetrated the upper few meters to recover finegrained to very fine-grained sand (Hogarth et al. 2007). The two others were centered over the two Oceanside chirp lines shown in Figure 3 and contained sediment of mean grain size $0.129 \mathrm{~mm}$ for the upper transparent body (Darigo and Osborne 1986). Grain lithologies were mainly terrigenous (quartz, feldspar, etc.), though with $27 \%$ shell fragments. Interpretations by Darigo and Osborne (1986) of further seismic profiles suggest that these bodies are common off the southern Californian coast.

Manawatu coast, New Zealand A similar erosional surface was interpreted by Dunbar and Barrett (2005) from 3.5-kHz sediment profiler data collected perpendicular to the Manawatu coast, New Zealand, beneath transparent deposits. Ignoring their profiles across rollovers where the data suggest that relief of underlying pre-Holocene formations may have affected the sediment accumulation (for example, because of lee-side deposition behind outcrops), one profile was selected for plotting in Figure 3, lying adjacent to a transect of 
measurements of surface grain size (at Peka Peka). Grain size at the depth of the rollover resolved here was $0.105 \mathrm{~mm}$.

Ascension Island, Atlantic Ocean High-resolution multibeam sonar data have been collected on the southwest shelf of Ascension Island by Thales Geosolutions Inc. for the US Air Force. Although sub-bottom and grain-size data are unfortunately lacking, the cross section shown in Figure 3 reveals a staircase of two rounded features that are morphologically similar to the other rollovers shown in this paper. As they have a smooth surface, rather than rugged volcanic surface texture of near-shore lava (Mitchell et al. 2008), they are interpreted as sandy clinoforms.

Atlantic Iberia The Iberian Atlantic data were collected near to Faro, Portugal. The first three profiles are from Lobo et al. (2005, their Figs 6, 8, and 5, respectively), and the fourth is from Hernández-Molina et al. (2000), all derived from boomer seismic records. The original data are of excellent quality and reveal a series of foresets dipping subparallel with the modern seabed, suggesting that sand accumulated on their seaward surfaces, as expected from seaward progradation. The extent of those foresets in the images also constrains any topset deposits or drape to only a few meters at most. The second of these profiles was acquired immediately south of Faro, where the coast is exposed to the Atlantic waves from the west, whereas the other Iberian Atlantic profiles lie adjacent to where the coast faces southeast into the Gulf of Cadiz.

Malabar Coast, Australia Field and Roy (1984) interpreted the transgressive erosional surface in seismic reflection data off southeast Australia and, above it, a series of sandy clinoforms. Besides foreset reflectors, their interpretations show some internal reflectors lying subparallel with the seabed, implying that these bodies developed by aggradation as well as progradation. Those shown in Figure 3 are from the Malabar Coast. The reflectors 
were weak, implying a relatively homogeneous sediment bulk density and sound speed. Although precise coordinates were not given, Field and Roy (1984) mentioned a 10-m vibracore taken through the sediment body here which recovered fine quartz sand. They mentioned that extensive surface sampling recovered fine- to medium-grained sand on the sand lobes. Fine- to medium-grained mainly quartz sand was also mentioned by Roy et al. (1994). In the following analysis, we use a wide range of grain size $(0.125-0.5 \mathrm{~mm})$ to reflect this uncertainty.

Monterey Bay, California Lastly, a profile from Monterey Bay was derived from boomer seismic results in Chin et al. (1988). It was reconstructed for a line perpendicular to the coast running from the mouth of the Salinas River (Figure 5) from their maps of bathymetry and two underlying reflector isopachs. Seismic profiles in Chin et al. (1988) reveal a prograding geometry as elsewhere. The bathymetry contours in Figure 5 are drawn every $10 \mathrm{~m}$ to $100 \mathrm{~m}$ depth using the Global Multi-Resolution Topography dataset (Ryan et al. 2009). Despite the irregularity of the contours (a result of the original hydrographic soundings), they reveal a bathymetric bulge of the clinoform at the river mouth. Modal grain size from seabed grabs reported by Dunbar and Barrett (2005) is a fine $0.105 \mathrm{~mm}$ sand at the depth of the rollover interpreted here, whereas sediment texture maps in Chin et al. (1988) suggest a $0.375 \mathrm{~mm}$ grain size at the rollover. Both of these grain sizes were used in the following estimates of threshold shear stresses. Given this clinoform's association with the Salina River, the supplied sediments probably have a greater range of grain sizes than the other sites and deposition may occur during river floods, not necessarily exactly at the same time as extreme wave conditions. This site is included to see if this leads to a different rollover location compared with the others. 
Rollover depths were needed in order to compute bed shear stresses. As a progressive seaward steepening of the seabed occurs across the clinoform, a rollover point is not easily interpreted by eye consistently, but the following procedure seemed to yield visibly reasonable rollover locations. The steepening was characterized from a general background gradient for each profile derived from the seabed shorewards of each sand body and from a maximum gradient from the clinoform foreset. The rollover point was then located where the change in gradient from the background value reached $40 \%$ of the latter maximum value. Those rollover depths are reported in Table 1 and shown by solid circles in Figure 3. The deepest rollovers lie off Australia whereas the shallowest rollovers lie off Oceanside, California.

\section{Relics of Deposition during Earlier Periods of Lower Sea Level?}

The deeper rollovers might potentially represent sand bodies that were deposited during earlier times when sea level was lower. Indeed, varied wave climate and erosion and other shoreline processes can be expected to modulate the supply of sand over time, and the deeper step shown on the Ascension Island profile (Figure 3) is presumably a relict clinoform as it is difficult to see how a constant wave climate could produce two clinoforms simultaneously (alternatively, it could have been created by other types of currents). The deepest of the clinoforms in Figure 3 that we study here, and therefore where this could be most worrisome, are those off Australia. Field and Roy (1984) cited a variety of evidence to argue that they are actively being modified by bottom currents, such as sidescan sonar data showing sharp boundaries between sand lobes and sharply defined channels in the landward side of the bodies containing rippled sand. They mentioned that a sample recovered from the base of the 10 - $\mathrm{m}$ vibracore at $55 \mathrm{~m}$ below sea level yielded a $\mathrm{C}^{14}$ date of $9500 \pm 105$ years. They also 
mention further unpublished radiocarbon data indicating that the sand bodies accumulated progressively over the past 12,000 years. Roy et al. (1994) showed vibracore data obtained from rollovers with various depths essentially showing accumulation continuing during the Holocene. Although higher-quality seismic data and vibracores would be needed for all of the sites studied here to resolve this issue unequivocally, the above observations suggest that all of the rollovers have probably been active in the Holocene.

\section{Wave Properties}

Given the difficulty of obtaining local wave-buoy data from all these sites, a database of deep-water wave properties was instead used to represent conditions at the clinoform rollovers. A modelling study of wave-rider data (Wright 1976) suggested that waves off Botany Bay, southeast Australia, lost only 3.4\% power on average through friction before reaching the near-shore zone of wave-induced sediment motion. The following procedure should therefore yield reasonable estimates of wave properties at the clinoforms where the shelf bathymetry gradient is similarly steep (producing little attenuation of waves through friction) and the coast exposed to ocean waves, but we return to this issue after describing the wave data processing.

We extracted 6-hourly estimates of deep-water mean wave period $\left(T_{a}\right)$, significant wave height $\left(H_{s}\right)$ and direction from the ERA-40 reanalysis model, which comprises wave properties computed from meteorological station (wind and pressure) data. The ERA-40predicted $H_{s}$ values have been validated against wave-buoy and satellite-altimetry data by Caires and Sterl (2003), who showed that $H_{s}$ is underestimated for extreme stormy conditions but otherwise well reproduced. A similar validation of $T_{a}$ found them accurately to reflect true conditions, except in swell-dominated sea states (Caires et al. 2005). Although swell- 
dominated seas are not typical of the energetic sea states associated with resuspension of sand in the surf zone and shoreface, a bias towards shorter periods could result. Although the upper percentiles of the data may not, strictly speaking, represent extreme storm conditions to a high accuracy, our conclusions concerning whether shear stresses exceed thresholds of motion discussed later should not be affected as bed shear stresses in the following are underestimated rather than overestimated.

The wave properties were extracted from the ERA-40 database for the period 1992-2001 from deep-water positions (unfilled circles in Figure 2) closest to each sandy clinoform. Those data were processed as follows to isolate larger waves most important for nearshore morphological change. Because wind-derived waves propagating parallel to shore could potentially be obstructed by headlands and nearshore shallows, and because individual nodes in a coarse-scale global model such as the ERA-40 can sometimes include wave fields that would not occur close to the shoreline (e.g., seaward-propagating waves), we first sorted the data using a weighting that excludes these unwanted wave directions. The following weighting tends to retain data representing waves propagating in a broad sector shorewards but not those propagating parallel to the coast. The plan-view angle $(\theta)$ between the propagation direction of the waves and a line drawn locally normal to the coastline was calculated (those normal orientations are given in the electronic supplement). Each 6-hourly $H_{s}$ value was then weighted by $\sqrt{ } \cos (\theta)$ and the series of positive $H_{s} \sqrt{ } \cos (\theta)$ sorted by increasing value. (The $\sqrt{ } \cos (\theta)$ weighting mainly reduces the importance of waves propagating close to the shoreline-orientation, having a value $>0.8$ within $50^{\circ}$ of the shoreline normal direction.) The upper 5- and 10-percentiles of those sorted $H_{s} \sqrt{ } \cos (\theta)$ values were selected. From those selected data, the mean values of $H_{s}$ and $T_{a}$ (without the weighting) were then calculated. Table 2 shows the results of this procedure. Throughout the 
following analysis, we use average period for all sites except for one where only peak period data were available from a wave-buoy report as explained below.

The ERA-40 data are unlikely to represent conditions at the rollovers where onshore propagation is disrupted by islands or attenuated by a wide, shallow shelf. For example, the studied site in the southern part of the Manawatu coast of New Zealand at Peka Peka is partially blocked by a headland of the South Island, and it lies beyond a wide shelf, so that site was excluded from the threshold analysis. Similarly, the islands off southern California distort waves reaching the Oceanside coast, though in complex ways that depend on wave direction and period (Rogers et al. 2007). Numerical model predictions typically show $H_{s}$ halved compared with Pacific deep water west of the Channel Islands (http://cdip.ucsd.edu/). Data from wave buoy "101" (Torrey Pines Inner) for the three years 2001-2004 were downloaded and analyzed. This buoy lies close to the Oceanside coast in $20 \mathrm{~m}$ water depth, near to the rollover depth in the CHIRP profiles. Because of the island effects, the $H_{s}$ and $T_{a}$ statistics used to calculate the mean oscillating current shown in Figure 6A are reduced by $63 \%$ and $31 \%$, respectively, compared with the ERA-40 predictions. We therefore used the wave-buoy data in the following calculations.

No ERA-40 data were available for the Mediterranean Iberia site, so data were extracted from a report on Spanish wave buoy 2548 sited near Cabo de Gata (Puertas del Estado, 2006). This buoy lies in deep water (368 m) close to the site of the clinoform shown in Figure 3. The table summarizing annual occurrences of $H_{s}$ and peak period $\left(T_{p}\right)$ was provided for the period 1998-2006 ( $T_{a}$ data were not available). It allowed mean $H_{s}$ and $T_{p}$ to be calculated for the upper $7.3 \%$ and $3.1 \%$ of the distribution, which we plot in place of the upper $10 \%$ and $5 \%$ in Figure 6 . The $H_{s}$ values will overrepresent the upper $10 \%$ and $5 \%$ values somewhat. Peak periods also tend to be larger than average periods in general. Bed 
shear stresses computed as described below from these values are therefore overestimates compared to the values that would have been computed for data more exactly comparable to the ERA-40 data. Nevertheless, these stresses are still useful as maximum bounds because the Mediterranean site has relatively small waves.

Data from a wave directional array ("061”) located just outside the marina in Monterey Bay provides an opportunity to compare nearshore properties directly with those in the ERA40 data. This site is an extreme example of blocking of waves by headlands. Because the other sites should not be so badly affected, these Monterey data suggest the maximum error expected in statistics derived from ERA-40 data. The data have been studied previously by $\mathrm{Xu}$ (1999), who is referred to for details. Figure 5 locates the site against the physiography of the bay and the bathymetry. It is in $15 \mathrm{~m}$ of water just $5 \mathrm{~km}$ south of the Salinas River mouth and the line of the profile shown in Figure 3. The Monterey Peninsula on the south side of the bay (Figure 5) blocks waves produced by southwesterly and southerly winds (Xu 1999). Therefore, the array often recorded waves of smaller amplitude and period than would be expected from the deep-water record, particularly in summer, as illustrated for the year 1992 in Figure 7. The average $H_{s}$ and $T_{a}$ values computed from the buoy data for 1992 are $1.17 \mathrm{~m}$ and $8.87 \mathrm{~s}$, respectively, while those for the top $10 \%$ are $2.49 \mathrm{~m}$ and $10.69 \mathrm{~s}$ and those for the top $5 \%$ are $2.79 \mathrm{~m}$ and $10.98 \mathrm{~s}$. The annual average $H_{s}$ is only slightly more than half the ERA-40 value $(2.1 \mathrm{~m})$, whereas $H_{s}$ and $T_{a}$ for the more extreme conditions (mostly during more favorable winter and autumn wind directions) are reduced by a lesser extent. The ERA$40 H_{s}$ and $T_{a}$ are $3.4 \mathrm{~m}$ and $11.8 \mathrm{~s}$, respectively, for upper $10 \%$ conditions and $3.7 \mathrm{~m}$ and 12.2 $\mathrm{s}$ for upper $5 \%$ conditions. These values were calculated using the directional sorting procedure with a coastline oriented $\mathrm{N} 010^{\circ} \mathrm{E}$. Given the more extreme effect of headland 
blocking here, ERA-40 wave statistics for the other sites after the sorting should represent in situ conditions sufficiently accurately for the following analysis.

From the wave properties given above and in Table 2, the sites with the deepest rollovers (off SE Australia) are not explained by especially longer-period or higher waves; indeed, the shallow Oceanside sites experience markedly longer-period waves. However, the shallow Mediterranean Iberian site with a shallow clinoform rollover does experience shorter-period and lower waves than the other sites, as would be expected from the limited fetch of the area. The differing rollover depths are not easily explained by differing wave properties, so we extend the analysis in the next section by estimating wave shear stresses compared with the local threshold of motion of the sediment.

\section{Bed Shear Stress at the Rollover}

The sediment grain sizes at the different rollovers are similar, composed mostly of a fine sand (Table 1), so the threshold of motion should be relatively uniform between these sites. The maximum oscillating current speed due to waves $u_{m}$ should therefore be uniform or at least not varying systematically with rollover depth if declining wave oscillations were the only processes controlling the onset of deposition at these points. Wave orbital maximum speeds were computed according to linear wave theory for water depth $z$ (Komar and Miller 1973):

$$
u_{m}=\frac{\pi H_{s}}{T \sinh (k z)}
$$


The parameter $k$ is the wave number equal to $2 \pi / L$, where $L$ is the wavelength calculated using the linear wave dispersion equation:

$$
L=\frac{g T^{2}}{2 \pi} \tanh \left(\frac{2 \pi z}{L}\right)
$$

Shoaling effects on $H_{s}$ were ignored given that the rollovers are in intermediate water (generally $z / L>0.1)$.

In Figure 6 (left panels), we show values of $u_{m}$ computed at the rollover depth from Equations 1 and 2 using the wave properties in Table 2. The data do not show a uniform peak current, so the deeper clinoforms are not explained simply by different wave period or height. The Monterey site is predicted to experience extreme wave-orbital currents due to its shallow depth and the long wavelengths associated with 12-s-period waves experienced there (arrows in Figure 6 connect the ERA-40 to the wave-buoy values).

The bed shear stresses due to these wave properties were also calculated and are shown in Figure 6 (right panels). The calculation used the procedure outlined in Soulsby (1997) as described in Appendix A. Calculations were made only for sites where information on sediment grain size is available (Table 1). The grain-size values allowed the bed Nikuradse roughness and thus the friction coefficient with the bed to be estimated, as well as the threshold of motion of the sediment. The latter was derived using the procedure in Soulsby (1997) based on an empirical formula of Soulsby and Whitehouse (1997) assuming a sediment density typical of quartz grains. Given the presence of some carbonate grains mentioned earlier, these threshold stresses are upper bounds. From the dispersion of the data used to constrain the mean threshold of motion shown in Soulsby (1997, Figure 20), the 
standard deviation of this shear-stress threshold is estimated visually to be $\pm 50 \%$. Two values of bed shear stress and threshold were calculated where two grain-size values are shown in Table 2, the former accounting for the different bed Nikuradse roughness values. Some of the values of bed shear stress for the Monterey Bay site exceed the bounds of the graph and are not shown.

Excluding the Monterey values, in Figure 6A, the average bed shear stresses at the rollovers are less than the threshold of motion and those for Monterey Bay are close to the threshold of motion if the wave-buoy data are used (star symbols). The bed shear stresses for the upper 10-percentile waves in Figure 6B appear roughly in agreement with the expected threshold of motion on average. However, the bed shear stresses for the upper 5-percentile waves in Figure 6C are generally larger than the expected threshold of motion. Furthermore, the $\pm 50 \%$ spread in threshold shear stresses in the experimental data (Soulsby 1997) suggests that individual comparisons between bed shear stress and thresholds will involve a similar level of uncertainty, but the shear stresses in Figure 6C exceed or equal thresholds for all of the data shown.

\section{Discussion}

The results shown in Figure 6 support the view that sediment is exported during energetic sea conditions from the shoreface and deposited at a depth below which the oscillating wave currents are below the threshold of motion of the sediment (Field and Roy 1984; HernándezMolina et al. 2000). The estimated bed shear stresses for the upper 10-percentile of conditions coincide most closely to the thresholds of motion, so they are proposed to be the most important for controlling the rollover depth. Average wave conditions are generally unable to mobilize sediments at the rollover depth, while upper 5-percentile wave conditions 
can mobilise sediments at depths significantly deeper than the rollover depth. However, some of the following factors may modify this simple view.

\section{Downwelling and Other Wind-Driven Currents off Del Mar, California}

Although physical conditions at the time of active sediment transport are unfortunately not presently available for all these areas, data from current meters deployed off Del Mar in California (Winant 1980) illustrate currents that could potentially also be produced by cyclonic wind patterns at other sites, and that may have a significant effect on the potential for sediment mobilization at the rollover depth. That deployment was $9 \mathrm{~km}$ north of the northernmost sandy clinoform recorded by Hogarth et al. (2007) (leftmost Oceanside profile in Figure 3). According to Winant (1980), one or two extreme wind systems pass up the coast of California each year, originating as tropical storms off Mexico. Figure 8 shows the across-shore (continuous lines) and along-shore components (dashed lines) of currents for one such offshore storm in September 1978. Initially strong winds drove surface currents with a landward component as well as the larger shore-parallel component. That onshore component of the surface current was balanced by an offshore current of order $10 \mathrm{~cm} / \mathrm{s}$ near the seabed seen in both the $60-\mathrm{m}$ and $15-\mathrm{m}$ depth, and to a lesser extent the $30-\mathrm{m}$ depth, nearbed current meters. Over the course of the following 24 hours, the near-shore currents diminished and occasionally reversed. During the initial rising stage of the storm, the strong seabed agitation by waves combined with the significant component of offshore near-bed water transport can be expected to have carried some suspended and bedload particles seawards.

We can speculate on the likely magnitudes of shear stresses induced on the bed from currents like those in Figure 8 if coupled with the more-extreme wave conditions in Table 2. 
We have followed the procedure of Soulsby (1997) as described in Appendix B. With a typical alongshore near-bed current speed of $0.4 \mathrm{~m} / \mathrm{s}$ at $30 \mathrm{~m}$ depth, the bed shear stress due to that current in the absence of waves would be $0.42 \mathrm{~Pa}$. Combined with the wave stress of 0.3 Pa for the upper 10-percentile waves (Figure 6), mean bed shear stress computed using Equation B1 would be $0.45 \mathrm{~Pa}$, i.e., mostly dominated by the current. However, the instantaneous maximum bed stress calculated using Equation B3 would be 0.75 and $0.54 \mathrm{~Pa}$ for where waves propagate parallel and orthogonal to the current, respectively. Although these values are only rough estimates, they suggest that the combined stress at the rollover would be greater than the threshold of motion. As advective water movements are likely to coincide with strong wave conditions, the shear stress at the rollover probably generally lies above threshold stresses during extreme wave conditions.

\section{Modelling of Circulation}

When surface wind stress produces a downwelling current, that current is likely to turn over the shelf at a finite distance from the coastline and thus the associated near-bed current may peak offshore, potentially affecting deeper rollovers more than shallower rollovers. This effect is illustrated by numerical modelling of Xing and Davies (2002) of wind-driven circulation on the Iberian shelf. For circulation induced only by wind, their model shows the offshore near-bed current increasing to a modest $6 \mathrm{~cm} / \mathrm{s}$ with distance to $10 \mathrm{~km}$ from the shore. When the effects of wind-wave currents were included, the bed shear velocity peaked sharply at around $15 \mathrm{~km}$ from the coast. On steeper coasts, the effect of downwelling could be more important for two reasons. First, the nonlinear interaction between waves and a steady current leads to higher combined stresses. A comparatively modest increase in downwelling current could affect the bed shear stress disproportionately. Second, on coasts 
that are steeper than the Iberian shelf (the shelf gradient in the Xing and Davies (2002) model was $<0.5^{\circ}$ compared with $>1^{\circ}$ gradient off Malabar (Field and Roy 1984)), the rapid deepening of the bathymetry with distance from the coast leads to less friction opposing the circulation except in the shallow water where friction from wave-current interactions is important. Thus, a more sharply turning circulation might be expected, influencing sand deposition at the deeper rollovers on steeper coasts described here.

\section{Further Measurements off California's Coast}

As many parts of the continental shelf of California are narrow and steep, and exposed to Pacific deep-water waves, the literature on other current meter measurements taken there is useful to address this issue. Not all the deployments captured storm conditions or storm conditions were not reported, but they illustrate a number of other interesting effects. A deployment of 16 current meters in San Pedro Bay (Hamilton et al. 2006; Noble et al. 2009) revealed only a modest $\mathrm{M}_{2}$ tidal current amplitude, which increased modestly from $1.5 \mathrm{~cm} / \mathrm{s}$ at $25 \mathrm{~m}$ depth to $2.5 \mathrm{~cm} / \mathrm{s}$ at $35 \mathrm{~m}$ (most sites studied here are unlikely to experience significant tidal currents). An analysis of data from the Santa Monica shelf revealed 2-5 hour pulses of bottom currents reaching $15-20 \mathrm{~cm} / \mathrm{s}$ capable of transporting coarse sand at a $70 \mathrm{~m}$ site. Noble and Xu (2003) attributed these pulses to internal tidal bores. Similar currents deeper in the continental slopes have been recorded elsewhere (Cacchione et al. 2002). Data collected south of the Oceanside area (Lerczak et al. 2003) revealed semidiurnal currents there greater at $30 \mathrm{~m}$ water depth than at $15 \mathrm{~m}$. The vigor of internal tidal currents depends on ocean stratification and on the gradient of the seabed relative to the characteristic gradients of the waves (Cacchione et al. 2002), so it is unfortunately difficult to say how they vary between the sites in Figure 3, but there is a potential for them to have increased stresses 
in the deeper sites. Oceanic eddies, geostrophic currents, and wind-driven flows preferentially affecting the outer shelf (Largier et al. 1993; Noble and Ramp 2000; Ryan and Noble 2005) are similarly difficult to anticipate but could affect deeper sites.

Overall, the evidence from the calculations of bed shear stress showing above-threshold stresses for the upper 5-percentile conditions (Figure 6) and the considerations of other current effects lead us to suggest that the clinoform rollover probably does not represent a simple boundary between bed shear stresses above threshold to those below threshold (Walsh et al. 2004). Instead it probably represents a transition over which the net seaward transport flux of sediment begins to decline sharply but with bedload transport continuing beyond the rollover.

\section{Depth of Rollover and Sea-Level Reconstruction}

The results cast doubt on a rigid connection between the rollover and sea level for coasts with high wave energy, because the compilation in Figure 6 contains rollover depths varying from 20 to nearly $60 \mathrm{~m}$. Furthermore, as outlined above, a number of factors besides wave stress affect rollover depth, a conclusion likely to apply also to muddy clinoforms. Caution is needed in interpreting sea level only from clinoform rollovers in seismic reflection data (alternatively, the 20-60 m range can be considered roughly the uncertainty when using these types of deposits to reconstruct sea level). Less equivocal evidence of sea level needs more detailed information on appropriate unconformities, such as from cores (Miller et al. 1998).

\section{$\underline{\text { River-Mouth Clinoforms }}$}

Although the origin of the Monterey Bay clinoform is different from the others shown here, we have included it for comparison. Friedrichs and Wright (2004) described how 
deposition of sediment from hyperpycnal outflow of some rivers can be modulated by wave action so that a clinoform develops beyond the river mouth. Hyperpycnal outflow caused by extreme rainfall in the river's catchment does not necessarily coincide with strong wave conditions, so export of sediment at this site could potentially coincide with more nearly average wave conditions. We have thus avoided combining this profile with the others. However, our calculations suggest very strong shear stresses at the Monterey clinoform rollover (Figure 6), and indeed the rollover is not so well pronounced (Figure 7), possibly because of erosion. Xu (1999) claimed that wave effects at the depth of the wave buoy array (15 m) could be sufficient even to cause sheet-flow conditions in the bed sand with a return period of only 6 days for fine sand and 110 days for coarse sand.

\section{Conclusions}

Bed shear stresses of waves at the rollovers of these sand bodies roughly coincide with the thresholds of motion of the sediment if the upper 10-percentile of the waves is used to calculate those stresses. The calculations also suggest that the upper 5-percentile waves would produce bed shear stresses exceeding the threshold of motion to depths below the rollovers. Other causes of bed shear stresses, such as from wind-driven and some tidal currents, are also likely to keep the stresses above threshold for significant proportions of time. The rollovers of these prograding clinoforms therefore do not represent simple thresholds of motion, but rather should be considered transitions over which the timeaveraged down-slope sediment flux starts declining and causes deposition.

\section{Acknowledgments}


The ERA-40 data were provided online by the European Centre for Medium-Range Weather Forecasts. We thank Grant Allen for help in extracting data from the database. Dr. Javier Hernández-Molina kindly responded to questions about the Spanish work on these features. Some of the thoughts here were prompted by discussions with Rui Quartau on similar features found around the Azores islands. We are grateful for detailed and thoughtful reviews on this paper by David Mallinson, Didier Granjeon, and Peter Burgess. We thank the US Air Force for permission to use high-resolution multibeam sonar data from the southwest shelf of Ascension Island (data kindly reproduced for us by Thales Geosolutions). Figures in this paper were created with the help of the "GMT" software system (Wessel and Smith 1991).

Table 1. Sources of data on near-shore sand body.

\begin{tabular}{|l|l|l|l|}
\hline Location & Source (their profiles) & Rollover depths (m) & $\begin{array}{l}\text { Grain size } \\
(\mathrm{mm})\end{array}$ \\
\hline Oceanside California & 1 (D1, D2) & $21.7,20.8$ & $0.129 \ddagger$ \\
\hline Peka Peka, New Zealand & $2(29)$ & 31.6 & $0.105 \S$ \\
\hline Ascension Is. & 3 & 30.7 & - \\
\hline Faro, Atlantic Iberia & 4 (Figs 5, 6), 5 (Fig. 4) & $46.3,43.6,37.5$ & - \\
\hline Faro, Atlantic Iberia & 4 (Fig 8) & 33.3 & - \\
\hline Almería, Mediterranean & 5 (Fig. 3) & 32.1 & $0.171,0.239 \dagger$ \\
\hline SE Australia & 6 (D, K, N, R) & $49.7,46.6,46.5,56.0$ & $0.125-0.5 \#$ \\
\hline Monterey Bay, California & 7 & 23.1 & $0.105 \S, 0.375 \xi$ \\
\hline
\end{tabular}

Sources are (1) Hogarth et al. (2007), (2) Dunbar and Barrett (2005), (3) unpublished

multibeam data collected by the US Air Force, (4) Lobo et al. (2005), (5) Hernández-Molina et al. (2000), (6) Field and Roy (1984), and (7) Chin et al. (1988). Grain-size data correspond to the depth of the rollover: $\$$ from Darigo and Osborne (1986), § from Dunbar and Barrett (2005), †unpublished grab samples taken $1 \mathrm{~km}$ from the rollover of HernándezMolina et al. (2000) in the topset and forest respectively (Figure 4), \#medium to fine sand from Field and Roy (1984), and $\xi$ from sediment texture maps in Chin et al. (1988). 


\section{Appendix A.}

Thresholds of motion were computed using the revised empirical formula of critical Shields stress $\left(\theta_{c r}\right)$ of Soulsby and Whitehouse (1997) reproduced in Soulsby (1997):

$$
\theta_{c r}=\frac{0.3}{1+1.2 D_{*}}+0.055\left(1-\exp \left(-0.02 D_{*}\right)\right)
$$

where the dimensionless grain size $D^{*}$ is

$$
D_{*}=\left(\frac{g(s-1)}{v^{2}}\right)^{1 / 3} d
$$

and $g$ is the acceleration of gravity $\left(9.81 \mathrm{~m} / \mathrm{s}^{2}\right), s$ is the ratio of grain to water density $(=2.58$ for quartz), $v$ is the water kinematic viscosity $\left(1.36 \times 10^{-6} \mathrm{~m}^{2} / \mathrm{s}\right)$, and $d$ is the grain diameter (m). The critical bed shear stress $\tau_{c r}$ in SI units is then

$$
\tau_{c r}=\theta_{c r} g \rho^{\prime} d
$$

where $\rho^{\prime}$ is the excess grain density in water $\left(2650-1027 \mathrm{~kg} / \mathrm{m}^{3}\right.$ for quartz).

To estimate the bed shear stress produced by waves, the orbital wave speed is used for the water speed above the bottom boundary layer. Soulsby's equation for the friction factor $f_{w r}$ was used:

$$
f_{w r}=0.237 r^{-0.52}
$$


where $r=A / k_{s}$ with $A=u_{m} T / 2 \pi$ is the bottom orbital amplitude with $u_{m}$ from Equation 1 and $k_{s}=2.5 \mathrm{~d}$ (Nikuradse roughness). The stress amplitude under waves $\tau_{w}$ ("skin friction") is then

$$
\tau_{w}=0.5 \rho_{w} f_{w} u_{m}^{2}
$$

where $\rho_{w}$ is the density of seawater $\left(1027 \mathrm{~kg} / \mathrm{m}^{3}\right)$.

\section{Appendix B.}

The combined stress from waves and currents was calculated according to procedures in Soulsby (1997). The mean shear stress experienced by the bed was most easily reproduced with the following:

$$
\tau_{m}=\tau_{c}\left(1+1.2\left(\frac{\tau_{w}}{\tau_{c}+\tau_{w}}\right)^{3.2}\right)
$$

where $\tau_{w}$ is the stress due to waves alone (Equation A5) and $\tau_{c}$ is the stress due to a current alone, which is calculated from

$$
\tau_{c}=\rho_{w} C_{d} \bar{U}^{2}
$$


where $C_{d}$ is the dimensionless friction parameter, here set equal to 0.0026 for unrippled sand (Soulsby 1983) as we are interested only in the skin-friction stress. $\bar{U}$ is the depth-averaged current, for which we have used the current recorded outside the bottom boundary layer. If $\phi$ is the angle between the steady current and the oscillating current, the maximum current is then given by

$$
\tau_{\max }=\left[\left(\tau_{m}+\tau_{w} \cos \varphi\right)^{2}+\left(\tau_{w} \sin \varphi\right)^{2}\right]^{0.5}
$$

\section{References}

Cacchione, D.A., Pratson, L.F., and Ogston, A.S., 2002, The shaping of continental slopes by internal tides: Science, v. 296, p. 724-727.

CAIRES, S., and STERL, A., 2003, Validation of ocean wind and wave data using triple collocation: Journal of Geophysical Research, v. 108, Paper C3098, doi:10.1029/2002JC001491.

CAires, S., Sterl, A., and Gommenginger, C.P., 2005, Global ocean mean wave period data: Validation and description: Journal of Geophysical Research, v. 110, Paper C02003, doi:10.1029/2004JC002631.

Chin, J.L., Clifton, H.E., and Mullins, H.T., 1988, Seismic stratigraphy and late Quaternary shelf history, south-central Monterey Bay, California: Marine Geology, v. 81, p. $137-157$.

DARIGO, N., and OsBORNE, R.H., 1986, Quaternary stratigraphy and sedimentation of the inner continental shelf, San Diego County, California, in Knight, R.J., and McLean, J.R., 
eds., Shelf Sands and Sandstones: Canadian Society of Petroleum Geologists, Memoir 11, p. 73-98.

DunBAR, G.B., and BARRETT, P.J., 2005, Estimating palaeobathymetry of wave-graded continental shelves from sediment texture: Sediimentology, v. 52, p. 253-269.

FernándeZ-SAlas, L.M., Dabrio, C.J., Goy, J.L., DíaZ del Río, V., ZaZo, C., Lobo, F.J., SANZ, J.L., and LARIO, J., 2009, Land-sea correlation between Late Holocene coastal and infralittoral deposits in the SE Iberian Peninsula (Western Mediterranean):

Geomorphology, v. 104, p. 4-11.

FIELD, M.E., and RoY, P.S., 1984, Offshore transport and sand-body formation - Evidence from a steep, high-energy shoreface, southeastern Australia: Journal of Sedimentary Petrology, v. 54, p. 1292-1302.

FLEMINGS, P.B., and GROTZINGER, J.P., 1997, STRATA: freeware for analysing clastic stratigraphic problems, GSA Today, v. 6, p. 1-7.

FRIEDRICHS, C.T., and WRIGHT, L.D., 2004, Gravity-driven sediment transport on the continental shelf: implications for equilibrium profiles near river mouths: Coastal Engineering., v. 51, p. 795-811.

Hamilton, P., Noble, M.A., LARgier, J., Rosenfeld, L.K., and Robertson, G., 2006, Cross-shelf subtidal variability in San Pedro Bay during summer, 2001: Continental Shelf Research, v. 26, p. 681-702.

HELlAND-HANSEN, W., and HAMPSON, G.J. 2009, Trajectory analysis: concepts and applications: Basin Research v. 21, p. 454-483.

Hernández-Molina, F.J., Fernández-SAlas, L.M., Lobo, F., Somoza, L., Díaz del Río, V., and AlVeiRnho DiAs, J.M., 2000, The infralittoral prograding wedge: a new large- 
scale progradational sedimentary body in shallow marine environments: Geo-Marine Letters, v. 20, p. 109-117.

Hogarth, L.J., BABCOCK, J., DRISCOll, N.W., DANTEC, N.L., HAAS, J.K., INMAN, D.L., and MASTERS,P.M., 2007, Long-term tectonic control on Holocene shelf sedimentation offshore La Jolla, California: Geology, v. 35, p. 275-278.

KAufMan, P., Grotzinger, J.P., and MCCORMick, D.S., 1991, Depth-dependent diffusion algorithm for simulation of sedimentation in shallow marine depositional systems, in Franseen, E. K., Watney, W. L., St. C. Kendall, C. G., and Ross, W., Sedimentary Modeling: Computer Simulations and Methods for Improved Parameter Definition, Kansas Geological Survey, Bulletin 233, p. 489-508.

Komar, P. D., AND MiLleR, M. C., 1973, The threshold of movement under oscillatory water waves: Journal of Sedimentary Petrology, v. 43, p. 1101-1110.

LARGIER, J.L., MAGNELL, B.A., and WinANT, C.D., 1993, Subtidal circulation over the northern California shelf: Journal of Geophysical Research, v. 98, p. 18,147-18,179. Le Dantec, N., Hogarth, L.J., Driscoll, N.W., BABCock, J.M., BARnhardt, W.A., and SCHWAB, W.C., 2010, Tectonic controls on nearshore sediment accumulation and submarine canyon morphology offshore La Jolla, Southern California: Marine Geology, v. 268, p. $115-128$.

LERCZAK, J.A., WinANT, C.D., and HENDERSHOTt, M.C., 2003, Observations of the semidiurnal internal tide on the southern California slope and shelf: Journal of Geophysical Research, v. 108, paper 3068, doi:10.1029/2001JC001128. Lobo, F.J., FernándeZ-SAlas, L.M., HernándeZ-Molina, F.J., GonZÁlez, R., Dias, J.M.A., DíAz DEL Río, G., and SomozA, L., 2005, Holocene highstand deposits in the 
Gulf of Cadiz, SW Iberian Peninsula: A high-resolution record of hierarchical environmental changes: Marine Geology, v. 219, p. 109-131.

MASTERS, P.M., 2006, Holocene sand beaches of southern California: ENSO forcing and coastal processes on millennial scales: Palaeogeography, Palaeoclimatology, Palaeoecology, v. 232, p. 73-95.

MCCAVE, I.N., 1984, Erosion, transport and deposition of fine-grained marine sediments, in Stow, D.A.V., and Piper, D.J.W., eds., Fine-Grained Sediments: Deep Water Processes and Facies: Oxford, Blackwell Scientific, p. 35-69.

Miller, K.G., Mountain, G.S., Browning, J.V., Kominz, M., Sugarman, P.J., ChristieBlick, N., KATZ, M.E., and WRIGHT, J.D., 1998, Cenozoic global sea level, sequences, and the New Jersey transect: Results from coastal plain and continental slope drilling: Reviews of Geophysics, v. 36, p. 569-601.

Mitchell, N.C., Beier, C., Rosin, P., Quartau, R., and TemPera, F., 2008, Submarine lava flows around the coasts of Pico Island, Azores: Geochemistry Geophysics Geosystems, v. 9, paper Q03024, doi:10.1029/2007GC001725.

Mitchell, N.C., and HuthnANCE, J.M., 2007, Oceanographic currents and the convexity of the uppermost continental slope: Journal of Sedimentary Research, v. 78, p. 29-44.

Niedoroda, A.W., Reed, C.W., Das, H., Fagherazzi, S., Donoghue, J.F., and CatTaneo, A., 2005, Analyses of a large-scale depositional clinoformal wedge along the Italian Adriatic coast. Marine Geology v. 222-223, p. 179-192.

Noble, M.A., Jones, B., Hamilton, P., Xu , J., Robertson, G., Rosenfeld, L., and LARGIER, J., 2009, Cross-shelf transport into nearshore waters due to shoaling internal tides in San Pedro Bay, CA: Continental Shelf Research, v. 29, p. 1768-1785. 
NoBLE, M.A., and RAMP, S.R., 2000, Subtidal currents over the central California slope: evidence for offshore veering of the undercurrent and for direct, wind-driven slope currents: Deep-Sea Research II, v. 47, p. 871-906.

NoBLE, M.A., and XU, J.P., 2003, Observations of large-amplitude cross-shore internal bores near the shelf break, Santa Monica Bay, CA: Marine Environmental Research, v. 56, p. 127-149.

PARKER, G., 2006, Theory for a clinoform of permanent form on a continental margin emplaced by weak, dilute muddy turbidity currents, in Parker, G., and Garcia, M., eds., River, Coastal and Estuarine Morphodynamics, Proceedings of the 4th International Association of Hydrauling Engineering and Research Symposium on River, Coastal and Estuarine Morphodynamics, p. 553-561.

Pirmez, C., Pratson, L.F., and SteCKLer, M.S., 1998, Clinoform development by advection-diffusion of suspended sediment: Modeling and comparison to natural systems: Journal of Geophysical Research, v. 103, p. 24,141-24,157.

Puertas Del Estado, 2006 Clima de oleaje, boya de Cabo de Gata conjunto de datos, (online report http://www.puertos.es/en/oceanografia_y_meteorologia/redes_de_medida/index.html accessed 2011).

Rabineau, M., Berné, S., Olivet, J.-L., Aslanian, D., Guillocheau, F., and Joseph, P., 2006, Paleo sea levels reconsidered from direct observations of paleoshoreline position during Glacial Maxima (for the last 500,000 yr): Earth and Planetary Science Letters., v. 252, p. 119-137.

RIVENAES, J.C., 1992, Application of a dual-lithology, depth dependent diffusion equation in stratigraphic simulation: Basin Research, v. 4, p. 133-146. 
RIVENAES, J.C., 1997, Impact of sediment transport efficiency on large-scale sequence architecture: results from stratigraphic computer simulation: Basin Research, v. 9, p. 91105.

Rogers, W.E., Kaihatu, J.M., Hsu, L., Jensen, R.E., Dykes, J.D., and Holland, K.T., 2007, Forecasting and hindcasting waves with the SWAN model in the Southern California Bight: Coastal Engineering, v. 54, p. 1-15.

Roy, P.S., Cowell, P.J., Ferland, M.A., and Thom, B.G., 1994, Wave-dominated coasts, in Carter, R.W.G., and Woodroffe, C.D., eds., Coastal Evolution. Late Quaternary Shoreline Morphodynamics: New York, Cambridge University Press, p. 121-186.

RyAN, H.F., and NoBle, M.A., 2005, Comparison of shelf currents off central California prior to and during the 1997-1998 El Nino: Continental Shelf Research, v. 25, p. 17871804.

Ryan, W.B.F., Carbotte, S.M., Coplan, J.O., O'Hara, S., Melkonian, A., Arko, R., Wiessel, R.A., Ferrini, V., Goodwillie, A., Nitsche, F., BoncZKowski, J., and ZEMSKY,R., 2009, Global multi-resolution topography synthesis: Geochemistry Geophysics Geosystems, v. 10, paper Q03014, doi:10.1029/2008GC002332.

SANGREE, J.B., and WIDMIER, J.M., 1977, Seismic stratigraphy and global changes in sea level, O, Seismic interpretation of depositional facies, in Payton, C.E., ed., Seismic stratigraphy: Applications to Hydrocarbon Exploration, American Association of Petroleum Geologists Memoir 26, p. 165-184.

SCHLAGER, W., and ADAMs, E.W., 2001, Model for the sigmoidal curvature of submarine slopes: Geology, v. 29, p. 883-886.

Soulsby, R., 1997, Dynamics of Marine Sands: A Manual for Practical Applications: London, Thomas Telford Ltd., 249 p. 
SoulSBY, R.L., 1983, The bottom boundary layer of shelf seas, in Johns, B., ed., Physical Oceanography of Coastal and Shelf Seas: Amsterdam, Elsevier, p. 189-266.

SOULSBy, R.L., and WHITEHOUSE, R.J.S.W., 1997, Threshold of sediment motion in coastal environments, Proceedings of Pacific Coasts and Ports '97 Conference, Christchurch, 1: Canterbury, University of Canterbury, New Zealand, p. 149-154.

Swenson, J.B., Paola, C., Pratson, L., Voller, V.R., and Murray, A.B., 2005, Fluvial and marine controls on combined subaerial and subaqueous delta progradation:

Morphodynamic modeling of compound-clinoform development: Journal of Geophysical Research, v. 110, paper F02013, doi:10.1029/2004JF000265.

SYVITSKI, J.P.M., and DAUGHNEY, S., 1992, DELTA2: Delta progradation and basin filling: Computers \& Geosciences., v. 18, p. 839-897.

VAIL, P.R., MitchUM, R.M., and ThOMPSON, S., 1977, Seismic stratigraphy and global changes of sea level; Part 4, Global cycles of relative changes of sea level, in Payton, C.E., ed., Seismic Stratigraphy - Applications to Hydrocarbon Exploration. American Association of Petroleum Geologists, Memoir 26, p. 83-97.

Walsh, J.P., NitTrouer, C.A., Palinkas, C.M., Ogston, A.S., Sternberg, R.W., and Brunskill, G.J., 2004, Clinoform mechanics in the Gulf of Papua, New Guinea: Continental Shelf Research, v. 24, p. 2487-2510.

WeSSEL, P., and SMITH, W.H.F., 1991, Free software helps map and display data: Eos, Transactions, American Geophysical Union, v. 72, p. 441.

WINANT, C.D., 1980, Downwelling over the Southern California Shelf: Journal of Physical Oceanography, v. 10, p. 791-799. 
WRIGHT, L.D., 1976, Nearshore wave-power dissipation and the coastal energy regime of the Sydney-Jervis Bay region, New South Wales: a comparison: Australian Journal of Marine and Freshwater Research, v. 27, p. 633-640.

XING, J., and DAVIES, A.M., 2002, Influence of wind direction, wind waves, and density stratification upon sediment transport in shelf edge regions: The Iberian shelf: Journal of Geophysical Research, v. 107, doi: 10.1029/2001JC000961.

XU, J.P., 1999, Local wave climate and long-term bed shear stress charactistics in Monterey Bay, CA: Marine Geology, v. 159, p. 341-353.

Young, A.P., RAymond, J.H., Sorenson, J., Johnstone, E.A., Driscoll, N.W., Flick, R.E., and GUZA, R.T., 2010, Coarse sediment yields from seacliff erosion in the Oceanside littoral cell: Journal of Coastal Research, v. 26, p. 580-585.

\section{Figures}

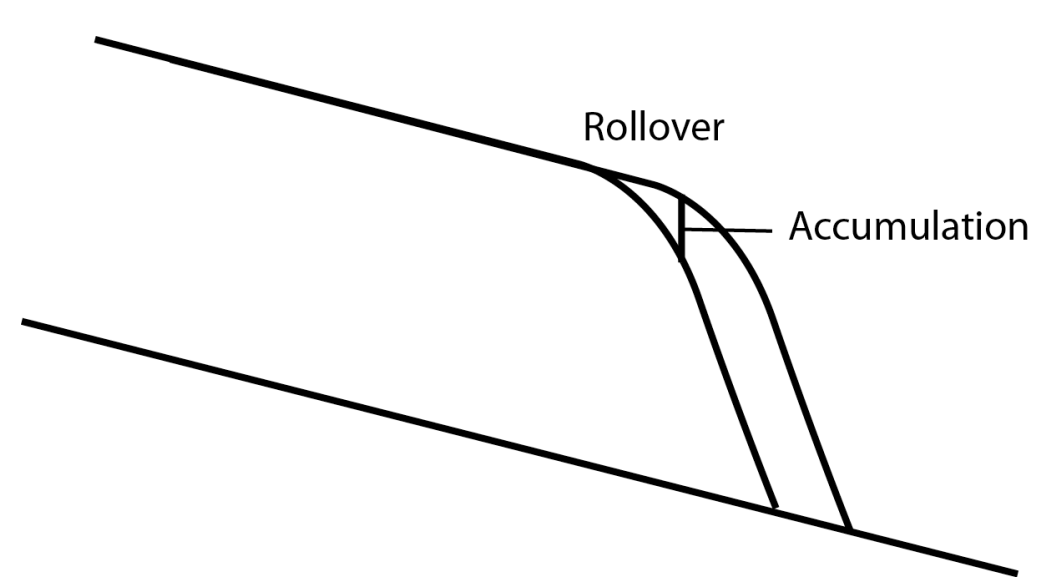

Figure 1. Geometry of a prograding clinoform is shown (strongly exaggerated vertically). In order to maintain the clinoform shape over time, deposition rates need to increase abruptly seawards over the rollover, as illustrated here by the difference between the two successive elevation profiles of the clinoform surface. 


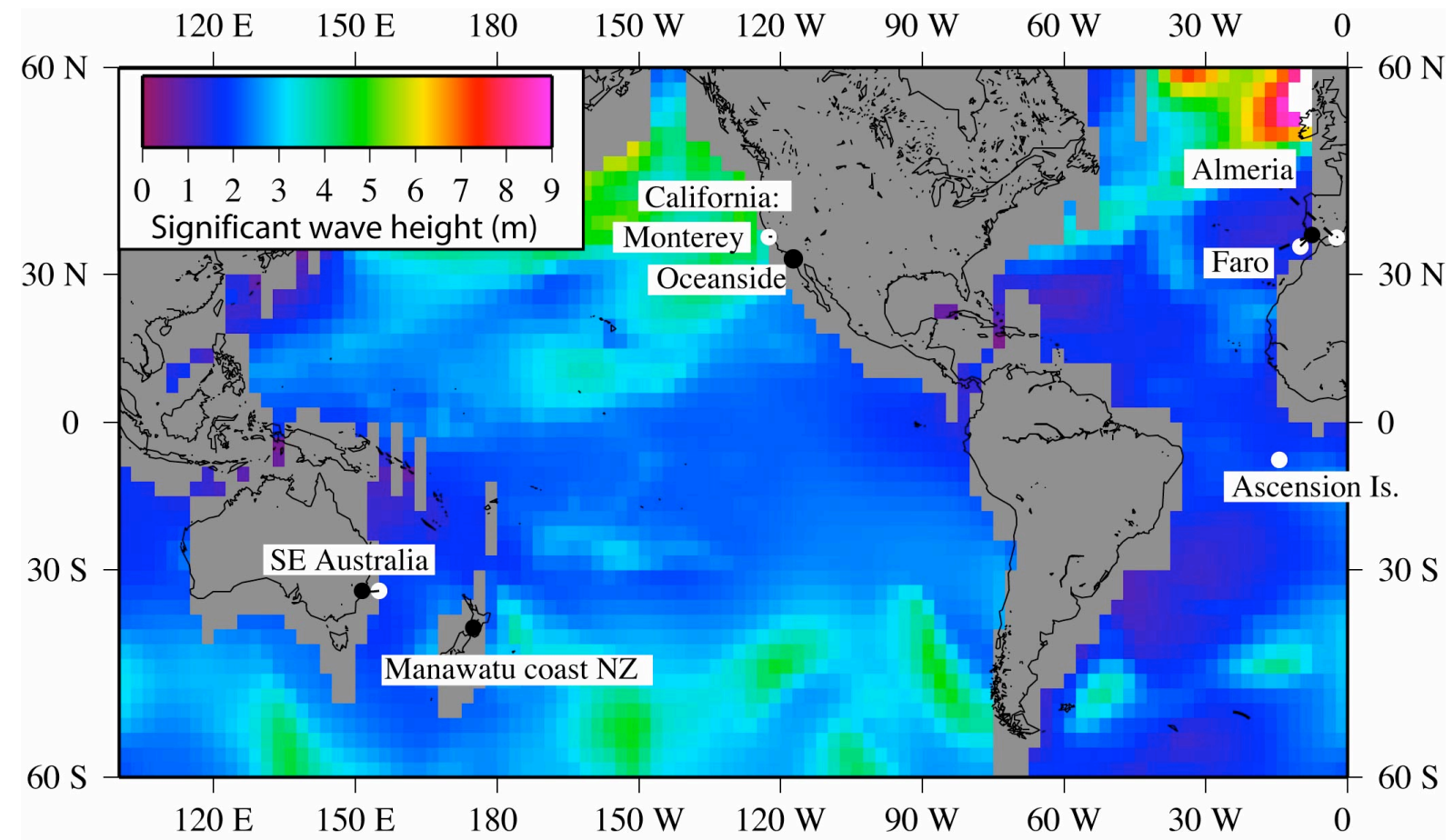

Figure 2. Locations of near-shore sandy clinoforms are shown with a background provided by an ERA-40 reconstruction of significant wave height for arbitrarily chosen midnight to 6 am 1 January 1992. Solid circles locate the sand bodies (Table 1) and unfilled circles where the wave reconstruction data were taken from.

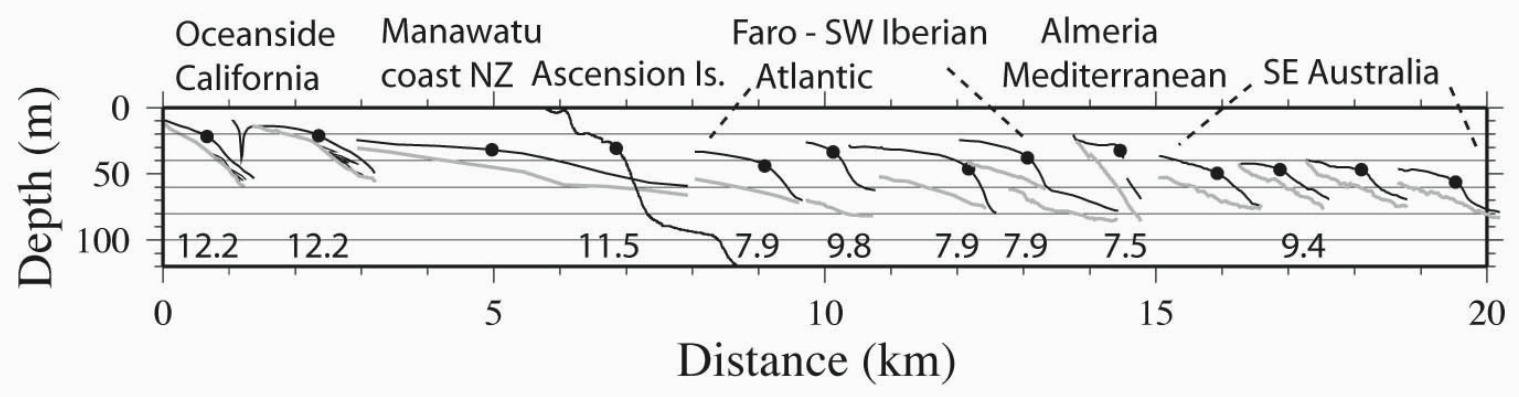

Figure 3. Topographic profiles of near-shore sand bodies from the sources given in Table 1 are shown with a 20:1 vertical exaggeration. Solid circles locate the rollover points. Gray 
lines represent the transgression surface where interpretable. Values shown beneath each profile are the average of the mean periods $T_{a}$ for the upper 5-percentile of incident waves. 
A)

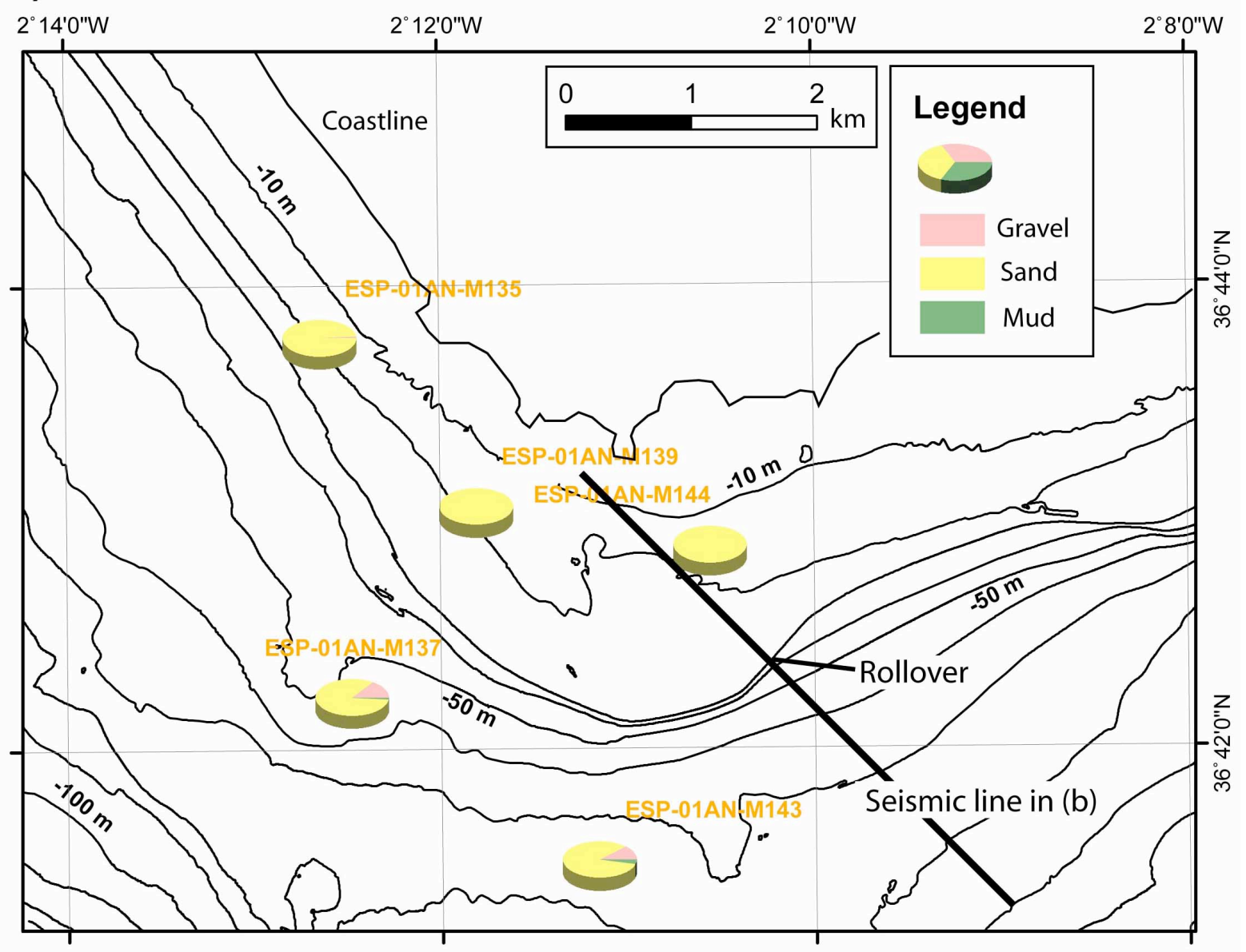

B)

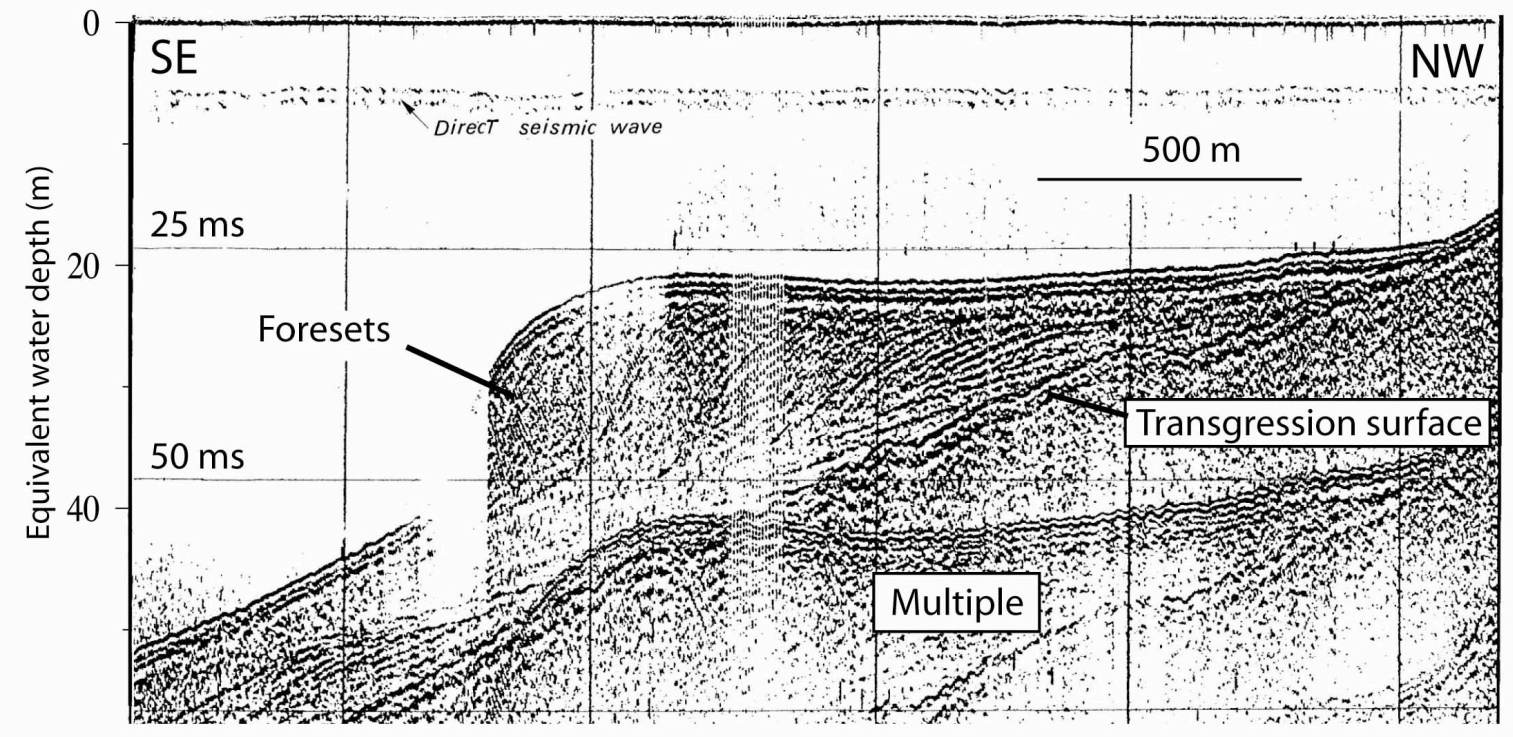


Figure 4. Clinoform near Almería, Spain. A. Shaded-relief image of multibeam echosounder data with $10-\mathrm{m}$ depth contours showing rounded body in plan view. Striping in the image is an artifact of motion-sensor errors and possibly tide-correction errors; besides these, the contours and surface texture suggest a smooth seabed around the rollover. Pie charts show the proportions of the basic sediment types in grab samples. B. Boomer seismic profile adapted from Hernández-Molina et al. (2000). Values to left are seismic two-way travel times in milliseconds and equivalent water depth in meters assuming a seismic velocity of $1500 \mathrm{~m} / \mathrm{s}$. Location is marked in Part A. 


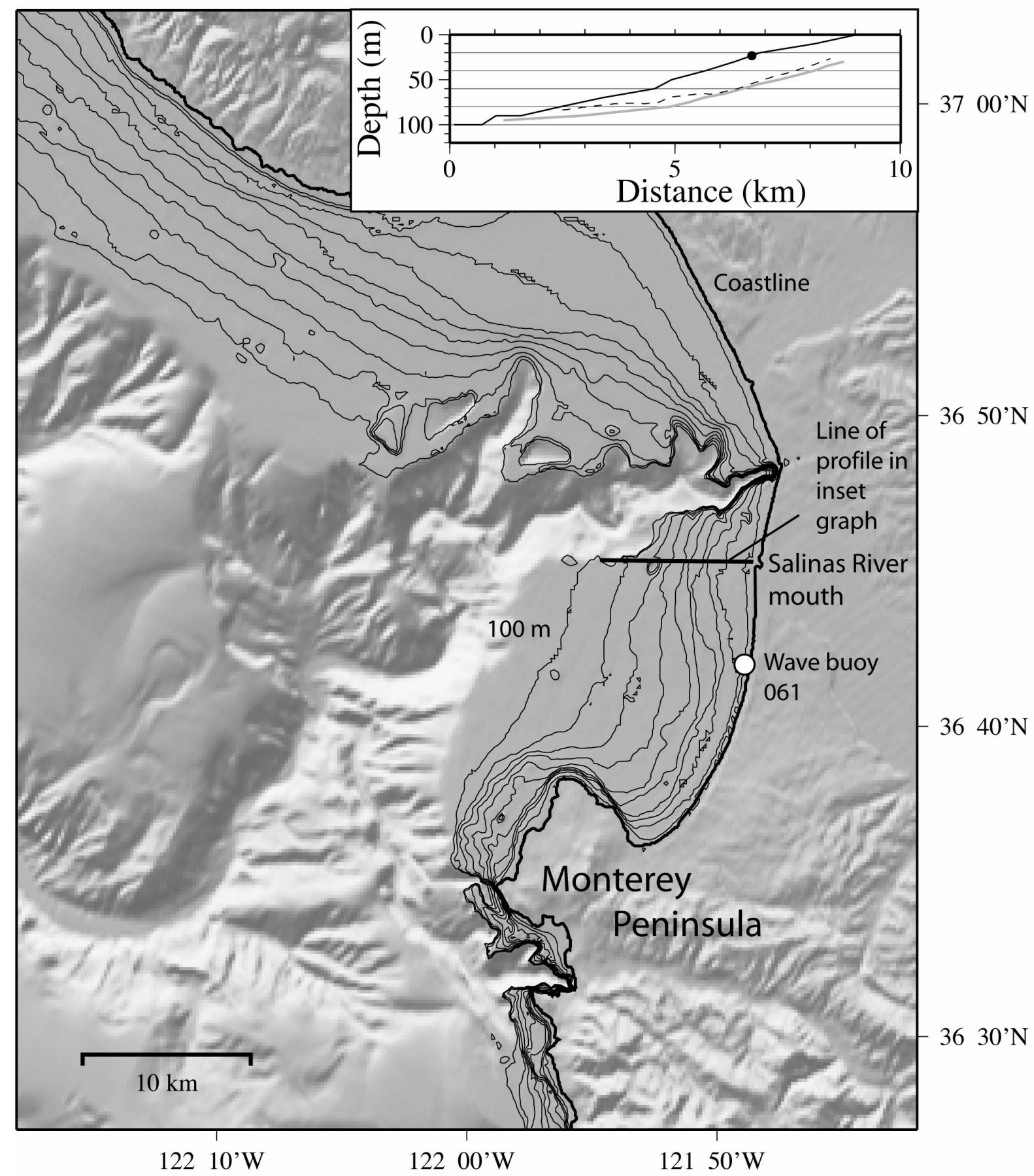

Figure 5. Location of wave buoy "061" within Monterey Bay, California. Topography from the Global Multi-Resolution Topography dataset (Ryan et al. 2009). Contours every $10 \mathrm{~m}$ are marked from the coastline down to $100 \mathrm{~m}$ depth. Profile in inset graph has the same 
vertical exaggeration as those in Figure 3 (dashed and gray lines are seismic reflections mapped by Chin et al. (1988)). 
A) Annual averages
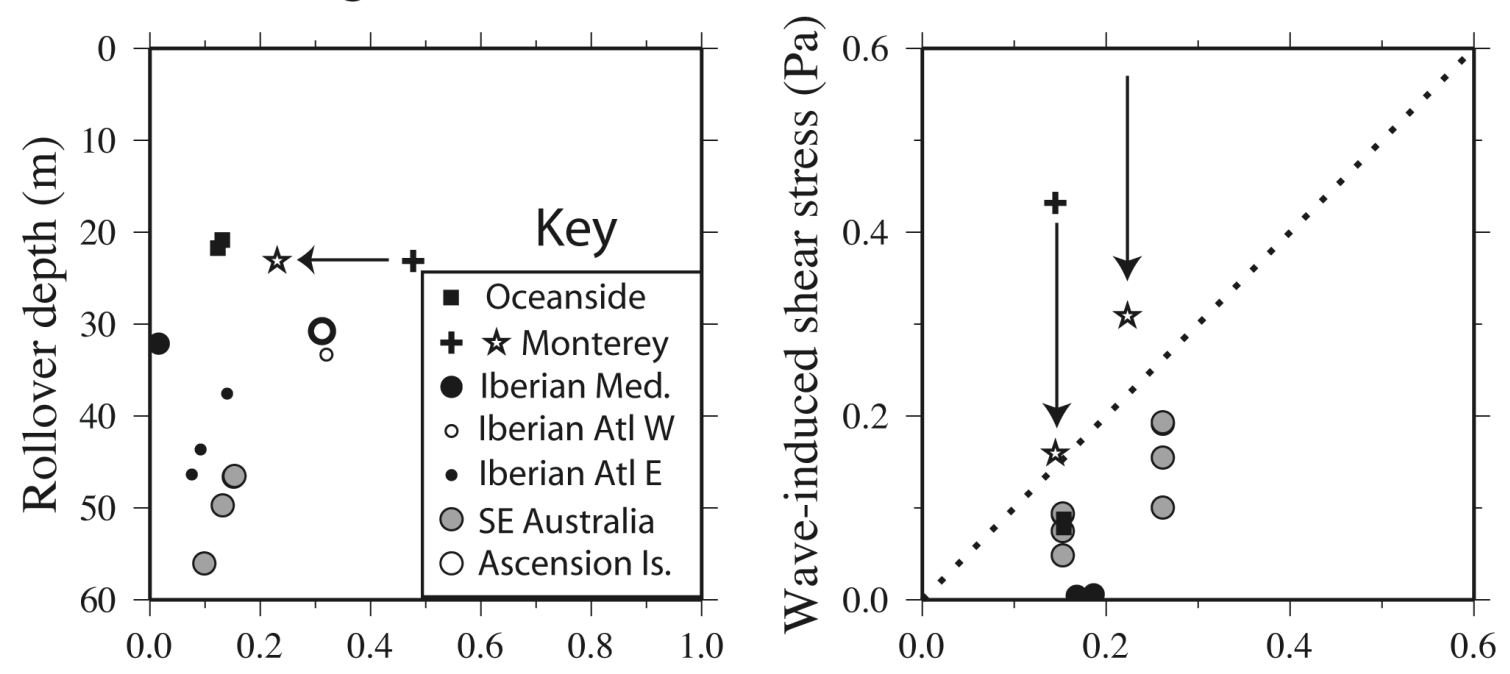

B) Upper 10-percentile
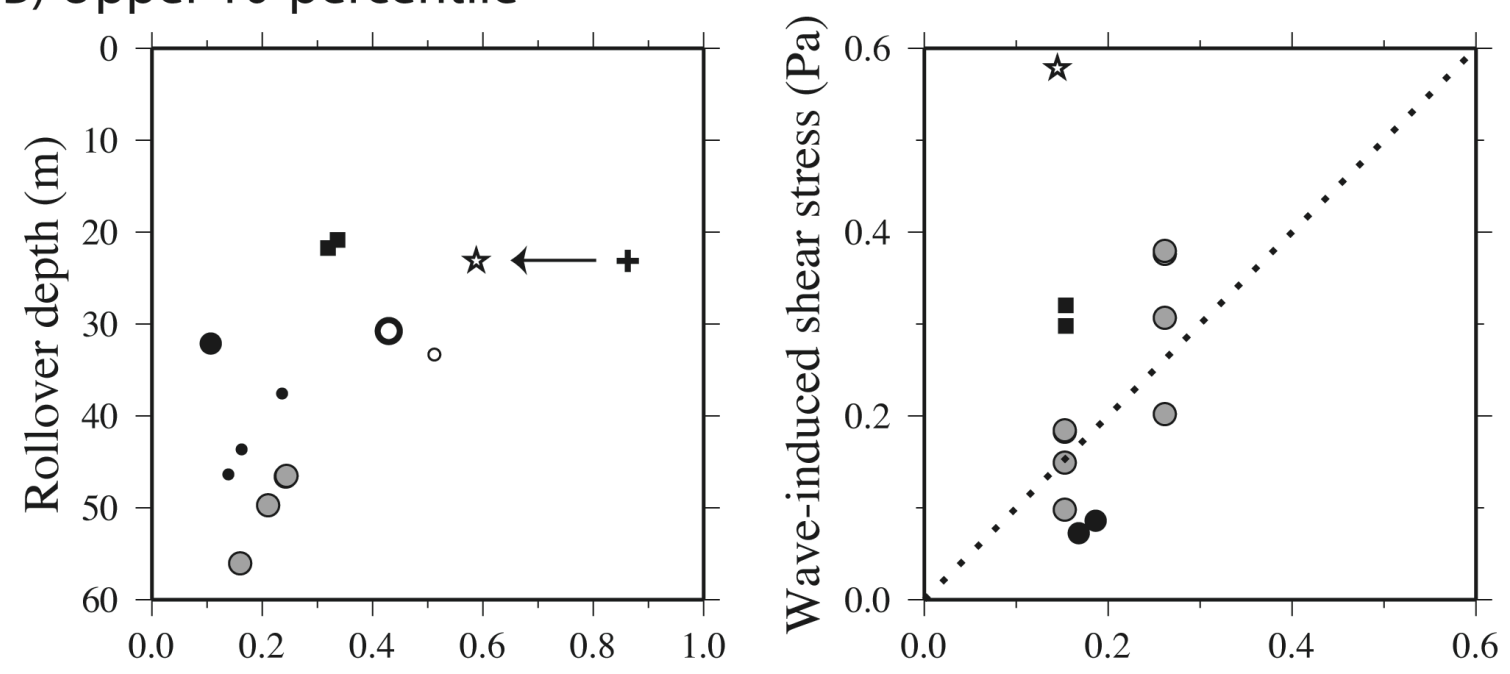

C) Upper 5-percentile
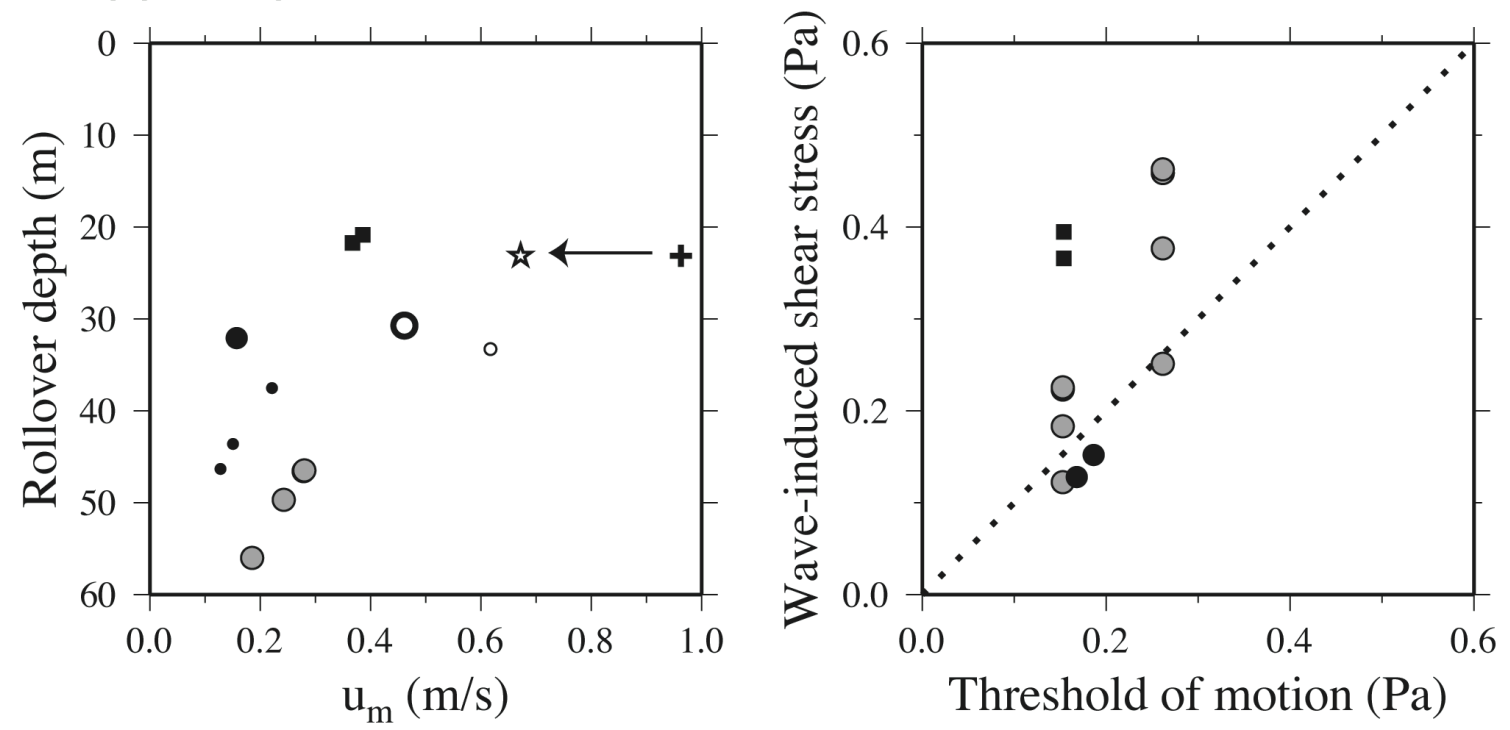
Figure 6. Maximum wave orbital currents and bed shear stresses at the rollovers. Two sets of values are shown in the right-hand graphs where two grain-size values are given in Table 1. Dotted lines in the latter graphs mark where a simple 1:1 relationship would appear. Values were calculated as described in the text using the ERA-40 and buoy wave properties given in Table 2. The star symbols represent values calculated using data from the Marina wave array in Monterey Bay $\left(H_{s}\right.$ and $T_{a}$ given in the main text) and "plus" symbols are values computed using the ERA-40 wave properties, illustrating the effect of headlands partially blocking waves at that site (see main text).
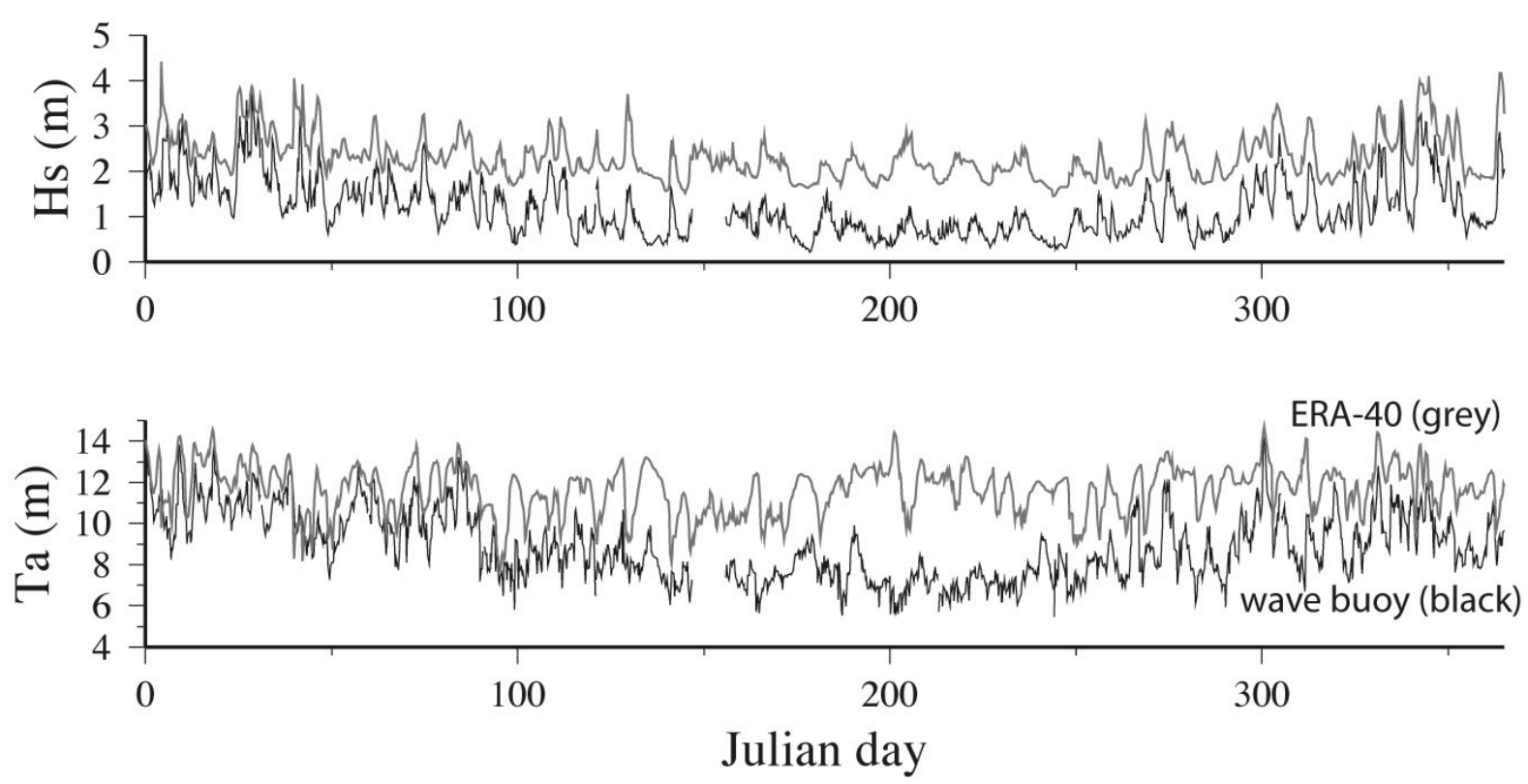

Figure 7. Record of significant wave height $H_{s}$ (top graph) and average period $T_{a}$ (lower graph) for the year 1992. Gray line represents the ERA-40 estimates, and continuous black line represents the data from wave buoy 061 located in Monterey Bay in Figure 5. 

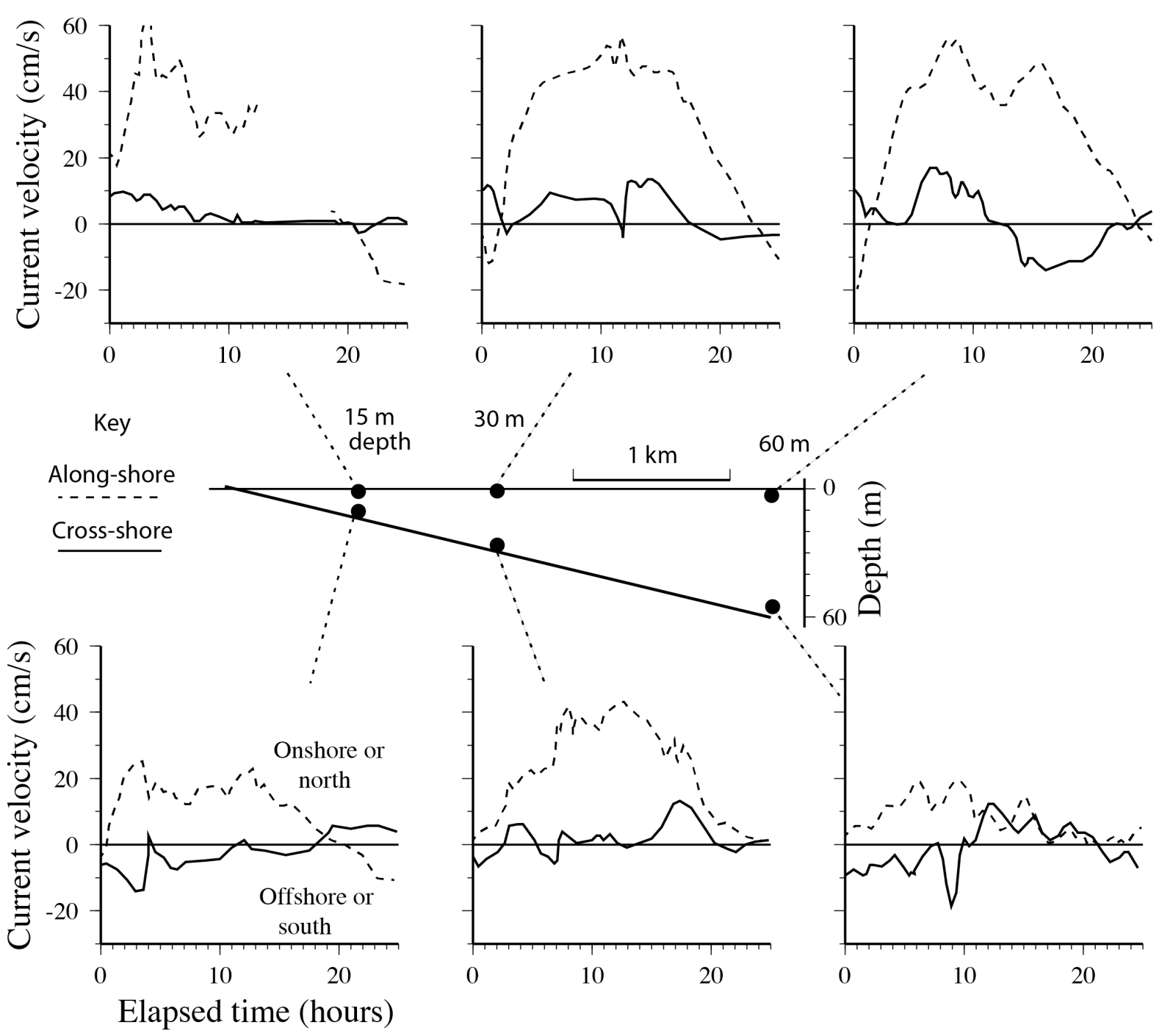

Figure 8. Data on surface (top) and bottom (lower) currents along a transect moorings located off Del Mar, California adjacent to the Oceanside profiles in Figure 3. Dashed lines represent along-shore component of currents (positive to north), and continuous lines represent across-shore component of currents (positive onshore). These data were derived from current-meter measurements of Winant (1980).

\section{Electronic supplement to "Near-shore sand bodies" by Mitchell et al.}

Shore-normal orientations used in sorting the ERA-40 wave data 


\begin{tabular}{|l|l|l|}
\hline Location & Source (their profiles) & $\begin{array}{l}\text { Shoreline-normal } \\
\text { orientation (degrees E of N) }\end{array}$ \\
\hline Ascension Is. & 3 & $070^{\circ}$ \\
\hline Faro, Atlantic Iberia & 4 (Figs 5, 6), 5 (Fig. 4) & $325^{\circ}$ \\
\hline Faro, Atlantic Iberia & 4 (Fig 8) & $035^{\circ}$ \\
\hline SE Australia & $6(\mathrm{D}, \mathrm{K}, \mathrm{N}, \mathrm{R})$ & $280^{\circ}$ \\
\hline Monterey Bay, California & 7 & $080^{\circ}$ \\
\hline
\end{tabular}

Sources as Table 1 in the main manuscript. These shore-normal orientations are landward. No sorting was applied to the Almería or Oceanside sites, as they were characterised by local wave buoy data. 